\title{
Maintenance Audit: the Tool for Maintenance Management Quality of Manufacturing Equip- ment
}

Václav Legát, Zdeněk Aleš, Tomáš Hladík

Faculty of Engineering, Czech University of Life Sciences Prague, Department for Quality and Dependability of Machines, Kamýcká 129, 16521 Prague 6 - Suchdol, Czech Republic, E-mail: legat@tf.czu.cz, ales@tf.czu.cz, hladik@tf.czu.cz

The purpose of this paper is to provide an overview of state-of-the-art of maintenance management audit and to show a case study of maintenance audit and its results in the Czech Republic. Authors proposed audit methodology based on world and own experiences. It was defined hundred thirty audit criteria divided into ten maintenance management areas. Using expert approach to review of maintenance managers and documentation according to audit criteria enables to obtain answers and their assessment presented in percentage of audit criteria fulfilment. After that there is applied SWOT analysis method to determine mainly weakness (gaps) in real maintenance management processes comparing with world excellence maintenance class. On the base of the gaps there are recommended topics for maintenance improvement. Value of the results is a help to maintenance managers and supervisors in maintenance audit executing as a tool for maintenance management improvement.

Keywords: Maintenance audit, Audit criteria, Criteria fulfilment, Quality assessment, Recommendation for improvement

\section{Acknowledgement}

Paper was created with the grant support - CZU CIGA 2015 - 20153001 - Use of butanol in internal combustion engines.

\section{References}

[1] ISO 9000:2015. Quality management systems - Fundamentals and vocabulary, pp. 51. International Organization for Standardization, Geneva

[2] ISO/IEC 17021:2011. Conformity assessment - Requirements for bodies providing audit and certification of management systems. International Organization for Standardization, Geneva

[3] CAMPBELL, J. D. (1995). Uptime: Strategies for Excellence in Maintenance management, pp. 384 Productivity Press

[4] WIREMAN, T. (2004). Benchmarking best practices in maintenance management. Industrial Press

[5] DENCZEW, S. (2007). Auditing as important element of modern water supply and sewage audit of systems management. In: Eksploatacja i niezawodność (Maintenance and reliability), No. 4, pp. 16-19

[6] SPORK, N. (2007). The way forward to excellence in maintenance. In: Eksploatacja i niezawodność (Maintenance and reliability), No. 4, pp. 77-78

[7] LEGAT, V., GRENCIK, J. (2007). Maintenance audit and benchmarking - search for evaluation criteria on global scale. In: Eksploatacja i niezawodność (Maintenance and reliability), No. 3, pp. 34-39

[8] IDCON: Strategy, Maintenance Assessment \& Improvement Plans [online]. [cit. 2015-10-05]. Available at: $\mathrm{http} / /$ www.idcon.com/consulting-implementation-training/implementation/strategy-maintenance-assessmentand-improvement-plans.html

[9] AL-MUHAISEN, M., SANTARISI, N. (2002). Auditing of the maintenance system of Fuhais plant/Jordan Cement Factories Co. In: Journal of Quality in Maintenance Engineering, Vol. 8 No. 1, pp. 62 - 76

[10] MACIÁN, V, TORMOS, B., SALAVERT, J. M., BALLESTER, S. (2010). Methodology applied for maintenance technical audit in urban transport fleets. In: Journal of Quality in Maintenance Engineering, Vol. 16, No. 1, pp. $34-43$

[11] AOUDIA, M., BELMOKHTAR, O., ZWINGELSTEIN, G. (2008). Economic impact of maintenance management ineffectiveness of an oil and gas company, In: Journal of Quality in Maintenance Engineering, Vol. 14, No. 3, pp. $237-261$

[12] DWIGHT, R. (1999). Searching for real maintenance performance measures, In: Journal of Quality in Maintenance Engineering, Vol. 5, No. 3, pp. $258-275$ 
[13] MULLER, M. (2013). Research of Renovation Possibility of Machine Tools Damage by Adhesive Bonding Technology. In: Manufacturing Technology, Vol. 13, No. 4, pp. 504 - 509

[14] NOVAK-MARCINCIN, J., JANAK, M., NOVAKOVA-MARCINCINOVA, L. (2012). Increasing of Product Quality Produced by Rapid Prototyping Technology. In: Manufacturing Technology, Vol. 12, No. 12, pp. 71 - 75

[15] KUMAR, U., GALAR, D., PARIDA, A., STENSTROM, C., BERGES, L., (2013). Maintenance performance metrics: a state-of-the-art review, In: Journal of Quality in Maintenance Engineering, Vol. 19, No. 3, pp. 233 277

[16] ISO 19011:2011. Guidelines for auditing management systems, pp. 44. International Organization for Standardization, Geneva

[17] EN 13460:2009. Maintenance-Documentation for maintenance. pp. 28. European Committee for Standardization

[18] EN 15341:2007. Maintenance - Maintenance Key Performance Indicators. pp. 32. European Committee for Standardization

[19] ISO 55000:2014. Asset management - Overview, principles and terminology, pp. 19. International Organization for Standardization, Geneva

[20] EN 16646:2014. Maintenance - Maintenance within physical asset management. pp. 40. European Committee for Standardization

Copyright (C) 2016. Published by Manufacturing Technology. All rights reserved. 